\title{
Growth Behavior of Wheat Cultivars under Different Levels of Nutrient Management
}

\author{
Manoj Kumar Gora ${ }^{1 *}$, M.Z. Siddiqui ${ }^{1}$, Shankar Lal Choudhary ${ }^{2}$ and \\ Kailash Chand Jakhar ${ }^{2}$ \\ ${ }^{1}$ Chandra Shekhar Azad University of Agriculture and Technology, Kanpur (U.P.), India \\ ${ }^{2}$ Sri Karan Narendra Agriculture University, Jobner, Jaipur (Rajasthan), India \\ *Corresponding author
}

\section{A B S T R A C T}

\section{Keywords}

RDF, FYM, RDN,

Fertility level.

Article Info

Accepted:

04 July 2017

Available Online:

10 September 2017
The present study was carried out at the student's instructional farm of Chandra shekhar Azad University of Agriculture and Technology, Kanpur, (U.P.) during rabi season of 2015-16. The experiment was conducted under split plot design with three replications, treatments comprising of two irrigation levels $\left(\mathrm{I}_{1^{-}}\right.$CRI, Booting and Milking stages and $\mathrm{I}_{2^{-}}$ CRI, Maximum Tillering, Booting and Milking stages) in main plots, two varieties (K 402 and $\mathrm{K}$ 1006) in sub-plots and four fertility levels $\left(\mathrm{F}_{1}-100 \% \mathrm{RDF}, \mathrm{F}_{2}-50 \% \mathrm{RDF}+5 \mathrm{t}\right.$ FYM, $\left.\mathrm{F}_{3}-50 \% \mathrm{RDF}+50 \% \mathrm{RDN}, \mathrm{F}_{4}-50 \% \mathrm{RDF}+50 \% \mathrm{RDN}+5 \mathrm{t} \mathrm{FYM}\right)$ in sub-plots. Results of present study revealed that fertility level $\mathrm{F}_{4}-50 \% \mathrm{RDF}+50 \% \mathrm{RDN}+5 \mathrm{t} \mathrm{FYM}$ proved to be the most productive and remunerative method for wheat production in central Uttar Pradesh conditions. It recorded highest grain yield (52.246 q/ha.) and straw yield (73.904 q/ha) as well as highest net return (Rs.72,666) and B:C ratio (1:3.12)than all other combinations followed in the experiment. However, variety K-1006 performed better than $\mathrm{k}-402$ with all treatment combinations.

\section{Introduction}

Wheat (Triticum aestivum L.) belonging to family poaceae is the single most important cereal crop, that has been considered as integral component of the food security system of several nations. It is important food crop of whole world. It is consumed mostly in the form of bread as "Chapati".

Wheat straw is used for feeding the cattle. Wheat contains more protein than other cereals and has relatively high content of Niacin and Thiamine. It is basically concerned in providing the characteristics substance "Glutien" which is very essential for bakery. The common bread wheat occupies more than $90 \%$ of the total wheat area with $10 \%$ area under Triticum aestivum $L$. India is major wheat producing country in the world. It ranks second after china and at present produce more wheat than the United States of America.

India occupied area under wheat 29.63 million ha with the production of 93.82 million tonnes and productivity of $35.21 \mathrm{qha}^{-1}$ grain during the year 2015-16.Uttar Pradesh with (30.20 million tonnes) production is to be the highest producer of wheat followed by 
Punjab (16.40 million tonnes), Madhya Pradesh (13.13 million tonnes), Haryana (11.10 million tonnes), Rajasthan (9.27 million tonnes) etc. In Uttar Pradesh is wheat grown on 9.6 million ha with average productivity of $4693 \mathrm{~kg}$ per ha (India statistics, 2016).

Nutrient elements of major significance for yield and quality of wheat are Nitrogen, Phosphorus, and Potash for getting higher yield and better quality of wheat. It is essential to carry out research on soil fertility for ascertaining the nutritional requirement of this crop. Nitrogen is an important metabolic element for growth and development of plant. It is considered as essential for synthesis of protein and others biochemical products of plant such as protoplasm, which is the basis of life.

The basic objective of the combined nutrient supply and management is to make, as for as possible balanced nutrient supply to crop that maintains the soil fertility and also sustained high productivity on a long term basis, as plant nutrient source differ markedly in their nutrient contents, release efficiency or fixation, positional availability, crop specificity and farmers' acceptability etc. Therefore, appropriate combinations to a production system for optimum and balanced nutrient supply depend on the land use, ecological, social and economic conditions.

\section{Materials and Methods}

The field experiment was conducted at students' instruction at farm of the C.S. Azad University of Agriculture and Technology, Kanpur. The field selected for experiment was well leveled and homogenous fertility having irrigation facility of tube well. The soil of experimental field was sandy loam in texture and neutral in $\mathrm{pH}$. The climate of Kanpur is sub-tropical, semi-arid with hot dry summer and severe cold in winter. Maximum temperature during summer reaches up to $46^{\circ} \mathrm{C}$, while during winter it falls up to $4^{\circ} \mathrm{C}$. The mean annual precipitation of the district is about $815.6 \mathrm{~mm}$ which is mostly received in the month of July to mid-September with occasional few showers of cyclonic rains during December and January. The total rainfall received $5.60 \mathrm{~mm}$ during crop growth period. The treatments in the experiment included scheduling of two irrigation levels and two cultivars.

The experiment was evaluated in split plot design with three replications. In each treatment, nitrogen was applied $50 \%$ as basal and remaining $50 \%$ in two split as top dressing at as CRI stage and tillering stage.

The required quantity of phosphorous and potassium was applied at the time of sowing in all the treatments. A half dose of nitrogen, full dose of phosphorus and potassium was applied uniformly in all the plots through urea, DAP and murate of potash, respectively at the time of sowing. Remaining half dose of nitrogen was top dressed between crown root initiation and tillering stages.

Two varieties were used (i) K-1006 is a new high yielding variety of wheat developed by Chandra Shekhar Azad Agriculture University, Kanpur, suitable north eastern plain zone that including state like eastern U.P., Bihar, West Bengal, Jharkhand \& Assam. It has consistently shown high degree of resistant to yellow rust, brown rust and black rust are most common disease that are found in wheat crop. (ii) K-402 (Mahi) was released from Chandra Shekhar Azad University of Agriculture and Technology, Kanpur (U.P.). The variety is recommended for Punjab, Haryana, Rajasthan and West U.P. etc. The varietal characters possess plant height varies between $80-90 \mathrm{~cm}$, average days for maturity is $130-135$ and test weight 
ranges $38-40$ gm. This variety also characterized as heat tolerant.

After pre - sowing irrigation, at proper moisture condition of soil, three ploughing were done with tractor drawn harrow followed by planking to achieve good tilth. The sowing of wheat seed (var. k-402, k-1006 @ $100 \mathrm{~kg} / \mathrm{ha}$ ) is done with desi plough on 28 November 2015. The spacing between row kept $20 \mathrm{~cm}$ and depth of sowing was $4-5 \mathrm{~cm}$. The irrigation was applied on physiological stages of crop growth. The irrigation depth was kept as $6 \mathrm{~cm}$ for all the irrigation treatment. The irrigation was applied at crown root initiation stage on 21 December 2015, maximum tillering stage 15 January 2016, Booting stage 10 February 2016, Milking stage 1 march 2016.Harvesting of crop was done manually with sickle at maturity on 5 April 2016.

\section{Results and Discussion}

\section{Growth and growth attributes}

Data shown in table 1 indicated that Initial plant population of wheat crop does not show significantly due to various levels of fertility applied to the crop. Plant height of wheat significantly improved with different fertility levels. Highest plant height of wheat at all physiological stages of crop growth was obtained with the fertility level of $50 \% \mathrm{RDF}+$ $50 \% \mathrm{RDN}+5 \mathrm{t}$ FYM. It might be due to the fact that integrated use of fertilizers increases the height of wheat plants in comparison to other level of fertilities. Similar results have also been reported by Chaturvedi (2006)

Plant fresh weight and dry matter accumulation per plant of wheat significantly improved with different fertility levels. Highest plant fresh weight at all the physiological stages of crop growth was obtained with the fertility level of $50 \% \mathrm{RDF}+$
$50 \% \mathrm{RDN}+5 \mathrm{t}$ FYM. The minimum plant fresh weight of wheat at all the physiological growth stages obtained with fertility level $50 \% \mathrm{RDF}+50 \% \mathrm{RDN}$. It might be due to the fact that balance use of organic and inorganic fertilizers increased the total leaf area, which results in higher fresh weight and dry matter accumulation per plant. These results are in close conformity with Meena et al., (2013).

\section{Yield attributes}

It was shown from the table 1 that Total number of spikes per meter length of wheat was significantly influenced with combined application of FYM and inorganic fertilizer. Fertility level of $50 \% \mathrm{RDF}+50 \% \mathrm{RDN}+5 \mathrm{t}$ FYM produced more no. of spikes per meter length of wheat as compare to other fertility levels. Fertility level of $100 \%$ RDF ranked second best treatment for producing more no. of spikes per meter length. Minimum no. of spikes per meter length of wheat was produced in $50 \%$ RDF $+50 \%$ RDN. Similar results have also been reported by Tanveer et al., (2010).

Grain weight per panicle of wheat was significantly influenced with combined application of FYM and inorganic fertilizer. Fertility level of $50 \% \mathrm{RDF}+50 \% \mathrm{RDN}+5 \mathrm{t}$ FYM produced more grain weight per panicle of wheat as compare to other fertility levels. Application of recommended dose $100 \%$ RDF ranked second best treatment for producing more weight of panicle. Minimum weight of panicle of wheat was produced in 50\% RDF + $50 \%$ RDN. Similar results have also been reported by Meena et al., (2013).

Test weight of wheat was significantly influenced with combined application of FYM and inorganic fertilizer. Application of recommended dose of $50 \% \mathrm{RDF}+50 \% \mathrm{RDN}$ $+5 \mathrm{t}$ FYM produced more test weight of wheat as compare to other fertility levels. 
Application of recommended dose $100 \%$ RDF ranked second best treatment for producing more test weight. Minimum test weight of wheat was produced in $50 \% \mathrm{RDF}+50 \% \mathrm{RDN}$. Similar results have also been reported by Youssef et al., (2013).

Table.1 Effect of different fertility levels on growth, yield and economics of wheat crop

\begin{tabular}{|c|c|c|c|c|}
\hline Particulars & $\mathbf{F}_{1}$ & $\mathbf{F}_{2}$ & $\mathbf{F}_{3}$ & $\mathbf{F}_{4}$ \\
\hline \multicolumn{5}{|l|}{ Growth attributing } \\
\hline Plant population meter length & 59.4 & 59.2 & 59.0 & 59.6 \\
\hline Plant height $(\mathrm{cm})$ & 96.28 & 95.28 & 94.36 & 97.64 \\
\hline Fresh weight (g) & 79.02 & 78.96 & 78.92 & 79.25 \\
\hline Dry weight $(\mathrm{g})$ & 15.92 & 15.87 & 15.58 & 16.42 \\
\hline \multicolumn{5}{|l|}{ Yield attributing } \\
\hline Total no spikes per meter length & 55.70 & 55.33 & 53.80 & 56.79 \\
\hline Grain weight per panicle $(\mathrm{g})$ & 2.89 & 2.50 & 1.76 & 3.22 \\
\hline Test weight $(\mathrm{g})$ & 46.04 & 45.70 & 44.83 & 47.13 \\
\hline \multicolumn{5}{|l|}{ Yield } \\
\hline Grain yield (q/ha) & 51.73 & 49.77 & 48.59 & 52.24 \\
\hline Straw yield $(\mathrm{q} / \mathrm{ha})$ & 68.43 & 68.01 & 65.64 & 73.90 \\
\hline Biological yield (q/ha) & 120.17 & 117.78 & 114.24 & 126.15 \\
\hline Harvest index & 43.17 & 42.25 & 42.53 & 41.46 \\
\hline \multicolumn{5}{|l|}{ Economics } \\
\hline Cost of cultivation & 47,767 & 46,746 & 45,663 & 47,663 \\
\hline Gross return & $1,14,411$ & $1,11,157$ & $10,8,151$ & $1,17,933$ \\
\hline Net return & 66,644 & 64,411 & 62,488 & 70,270 \\
\hline $\mathrm{B}: \mathrm{C}$ ratio & $1: 2.39$ & $1: 2.37$ & $1: 2.36$ & $1: 2.47$ \\
\hline \multicolumn{5}{|l|}{ Moisture studies } \\
\hline Consumptive use of water & 25 & 24 & 23 & 18 \\
\hline Total water use $(\mathrm{mm})$ & 543.4 & 546.4 & 569.6 & 544.4 \\
\hline Water use efficiency (kg/ha-mm) & 9.16 & 9.47 & 8.53 & 9.60 \\
\hline
\end{tabular}

${ }^{*} \mathrm{~F}_{1}-100 \% \mathrm{RDF}, \mathrm{F}_{2}-50 \% \mathrm{RDF}+5 \mathrm{t} \mathrm{FYM}, \mathrm{F}_{3}-50 \% \mathrm{RDF}+50 \% \mathrm{RDN}, \mathrm{F}_{4}-50 \% \mathrm{RDF}+50 \% \mathrm{RDN}+5 \mathrm{t} \mathrm{FYM}$

\section{Yield}

Table 1 shows that Grain yield of wheat was significantly influenced by combined application of FYM and inorganic fertilizer. Application of recommended dose of 50\% $\mathrm{RDF}+50 \% \mathrm{RDN}+5 \mathrm{t}$ FYM produced more grain yield of wheat as compare to other fertility levels. Application of recommended dose $100 \%$ RDF ranked second best treatment for producing more grain yield. Minimum grain yield of wheat was produced in 50\% $\mathrm{RDF}+50 \% \mathrm{RDN}$.

The increase in grain yield and straw yield with the application of higher dose of fertilizers might be due to higher number of tillers, higher dry matter accumulation and improved yield attributes on account of balance nutrition of the crop, which finally improved the grain and straw yields of wheat. Similar results have also been reported by several workers Shah et al., (2010).

Biological yield of wheat was significantly influenced by combined application of FYM and inorganic fertilizer. Application of recommended dose of $50 \% \mathrm{RDF}+50 \% \mathrm{RDN}$ $+5 \mathrm{t}$ FYM produced more biological yield $(126.150 \mathrm{q} / \mathrm{ha})$ of wheat as compare to other fertility levels. Application of recommended dose $100 \%$ RDF ranked second best treatment 
for producing more biological yield. Minimum biological yield (114.246q/ha) of wheat was produced in 50\% RDF $+50 \%$ RDN. These results are in close conformity with Rather and Sharma (2009).

Harvest index of wheat was significantly increased by different fertility levels. Significantly higher harvest index $(43.172 \%)$ of wheat was obtained with application of recommended dose of $100 \% \mathrm{RDF}$ as compared to recommended dose of other fertility level. Minimum harvest index $(41.464 \%)$ of wheat was recorded with the application of $50 \% \mathrm{RDF}+50 \% \mathrm{RDN}+5 \mathrm{t}$ FYM. This might be on account of increased vegetative growth which could not be transformed in to grain in same proportion under higher levels of FYM and inorganic fertilizers. These results are in close conformity with Yassen et al., (2010).

\section{Economics}

It is revealed from the data that Cost of cultivation was highest at application of recommended dose of $100 \% \mathrm{RDF}$ as compared to recommended dose of other fertility level. Minimum cost of cultivation was obtained in application of recommended dose of 50\% RDF + 50\% RDN. Gross return, net return was highest at application of recommended dose of 50\% RDF + 50\% RDN $+5 \mathrm{t}$ FYM as compared to recommended dose of other fertility level. Minimum gross return and net return was obtained in application of recommended dose of $50 \% \mathrm{RDF}+50 \%$ RDN. The B: $\mathrm{C}$ ratio was highest at application of recommended dose of 50\% $\mathrm{RDF}+50 \% \mathrm{RDN}+5 \mathrm{t} \mathrm{FYM}$ as compared to recommended dose of other fertility level. Minimum B: C ratio was obtained in application of recommended dose of 50\% $\mathrm{RDF}+5 \mathrm{t} F \mathrm{FM}$. The increase in gross and net return with combined application of FYM and inorganic fertilizers might be due to increase in grain and straw yield of wheat. The similar results have also been reported by Yassen $e t$ al., (2010).

\section{Moisture studies}

Effect of fertility on consumptive use of water was recorded higher in recommended use of $50 \% \mathrm{RDF}+50 \% \mathrm{RDN}+5 \mathrm{t} \mathrm{FYM}$ than other levels of fertility. Effect of fertility on consumptive use of water was recorded higher in recommended use of $100 \%$ RDF and $50 \% \mathrm{RDF}+50 \% \mathrm{RDN}$ respectively. Water use efficiency was recorded highest at fertility level of $50 \% \mathrm{RDF}+50 \% \mathrm{RDN}$ followed by 50\% RDF + 5t FYM, 50\% RDF $+50 \% \mathrm{RDN}+5 \mathrm{t} \mathrm{FYM}$ and $100 \% \mathrm{RDF}$ respectively. Total water use was recorded highest at fertility level of 50\% RDF $+50 \%$ $\mathrm{RDN}+5 \mathrm{t}$ FYM followed by $50 \% \mathrm{RDF}+5 \mathrm{t}$ FYM, 50\% RDF + 50\% RDN and 100\% RDF respectively.

\section{References}

Chaturvedi, I., 2006. Effects of phosphorus levels alone or in combination with phosphate-solubilizing bacteria and farmyard manure on growth, yield and nutrient up-take of wheat (Triticum aestivum L). Journal of Agriculture and Social Sciences 2:96-100.

India statistics, 2016

Meena, V.S., Maurya B. R., Verma R., Meena R., Meena R. S., Jatav G. K. and Singh D. K. 2013. Influence of growth and yield attributes of wheat (Triticum aestivum $L$.) by organic and inorganic sources of nutrients with residual effect under different fertility levels. The bioscan, 8 (3): 811-815.

Rather, S.A., Sharma, N. L. 2009. Effect of integrated nutrient management (INM) in wheat on soil properties and fertility status. Asian Journal of Soil Science 4 (1):55-57. 
Shah, A., Shafi, M., Bakht, J., Mohammad, W., Shah, M. and Raziuddin 2010. Effect of integrated use of nitrogen on yield and $\mathrm{N}$ uptake of maize crop. Pakistan Journal of Botany 42 (5): 3633-3638.

Tanveer, S.K., Yasmin, S., Husain, I., Mujahid, M.Y., Munir, M. and Asif, M. 2010. Wheat production and quality affected by different combination of fertilizer NP and farm yard manure in rainfed area. Pakistan Journal of Agricultural Research 23 (1-2): 94-97.
Yassen, A.A., Khaled, S.M. and Sahar, M.Z. 2010. Response of wheat to different rates and ratios of organic residues on yield and chemical composition under two types of soil. Journal of American Science 6 (12): 858-864.

Youssef, M.A., Sayed M. M. and Sadek I. 2013. Impact of Organic Manure, BioFertilizer and Irrigation Intervals on Wheat Growth and Grain Yield American-Eurasian J. Agric. \& Environ. Sci., 13 (11): 1488-1496.

\section{How to cite this article:}

Manoj Kumar Gora, M.Z. Siddiqui, Shankar Lal Choudhary and Kailash Chand Jakhar. 2017. Growth Behavior of Wheat Cultivars under Different Levels of Nutrient Management. Int.J.Curr.Microbiol.App.Sci. 6(9): 200-205. doi: https://doi.org/10.20546/ijcmas.2017.609.027 